\title{
The Role of Vehicle Speed Management in Urban Air Pollutant Emission Reduction
}

\author{
Adyati Yudison 1,2,*, Driejana ${ }^{2}$, Iman K. Reksowardojo ${ }^{3}$, Aminudin Sulaeman ${ }^{4}$ \\ ${ }^{1,2}$ Doctoral Student, Environmental Engineering Graduate Program, Institut Teknologi Bandung \\ ${ }^{2}$ Air and Waste Research Group, Faculty of Civil and Environmental Engineering, Institut Teknologi Bandung \\ ${ }^{3}$ Energy Conversion Research Group, Faculty of Mechanical and Aerospace Engineering, Institut Teknologi \\ Bandung \\ ${ }^{4}$ Analytical Chemistry Research Group, Faculty of Mathematics and Natural Science, Institut Teknologi Bandung \\ *Corresponding author: adyati@gmail.com
}

\begin{abstract}
Lack of mass transit facilities in urban area leads motorcycle to become the most chosen vehicle mode in Indonesia. It accounts for approximately $80 \%$ of the total motorized vehicle population. Increasing in motor vehicle population causes traffic congestion and lower traffic speed, hence higher emissions that worsen urban air quality. This paper aims to investigate relationship of vehicle travelling speeds and $\mathrm{CO}_{2}, \mathrm{CO}$ and $\mathrm{HC}$ emission profiles of the typical motorcycle used in Indonesia. Exhaust emissions of $\mathbf{2 0}$ motorcycles were tested using autocheck analyzer on idle and speed variations of, 10, 20, 30, 40, 50, and $60 \mathrm{kph}$ on a chassis dynamometer. For idle condition average emission rates of $\mathrm{CO}_{2}, \mathrm{CO}$ and $\mathrm{HC}$ were $0.16,0.03$ and $0.002 \mathrm{~g} / \mathrm{s}$, respectively. The results show that the highest $\mathrm{CO}_{2}$ and $\mathrm{HC}$ emissions of $82.30 \mathrm{~g} / \mathrm{km}$ and $0.55 \mathrm{~g} / \mathrm{km}$, respectively, found at $10 \mathrm{kph}$. The lowest emissions were found at $60 \mathrm{kph}$ speed with $\mathrm{CO}_{2}$ emission rate of $27.03 \mathrm{~g} / \mathrm{km}$ and $\mathrm{HC}$ of $0.10 \mathrm{~g} / \mathrm{km}$. Carbon monoxide (CO) showed slightly different emission pattern, with $12.85 \mathrm{~g} / \mathrm{km}$ found at $20 \mathrm{kph}$ and $4.18 \mathrm{~g} / \mathrm{km}$ at $50 \mathrm{kph}$. In general, the result shows that the higher the speed the lower the $\mathrm{CO}_{2}, \mathrm{CO}$, and HC emissions. Emission profiles indicate that the speed between $30-50 \mathrm{~km} / \mathrm{h}$ could be recommended as the most suitable traffic speed in urban area to ensure mobility, safety as well as the lowest emissions. The results are valuable as input to transportation management as a part of environmentally sustainable transportation.
\end{abstract}

Keywords - traffic congestion, transportation management, speed-related emission, air quality management, vehicle emission, air pollution

\section{INTRODUCTION}

$\mathrm{T}_{\mathrm{r}}$ raffic congestion become a serious problem in many city around the world. Many research was conducted to quantify its cost which associated with many factor. There are many factor affecting traffic congestion cost which associate with the disruption of unpredictable traffic delay, inconvenient schedule to avoid traffic congestion, extra fuel charge, accidents and air pollution [1]. Furthermore, some other researches were conducted to investigate emission during traffic congestion, which found that emission tend to be higher when congestion happened [2-4]. This findings give insight that traffic congestion, which cause low speed vehicle mobility, have negative impact for the population.

This issue should become a concern, while the Sustainable Development Goals (SDGs) program has goals to make cities inclusive, save, resilient and sustainable. One of the target is reducing the adverse per capita environmental impact of cities, including by paying special attention to air quality [5]. One of concept that could be used to manage this issue is environmentally sustainable transportation (EST). EST can facilitate the recent need of transportation while preserves the environment for the next generation needs. That concept integrating many aspect including roadside air quality monitoring and assessment. The result of monitoring and assessment will become the input to for better transportation management strategy [6].

As the lack of mass transit facilities, Indonesia faced many transportation problem. One of the biggest problem is the rapid growth of private motorized vehicle on the road especially motorcycle. Those increasing population cause traffic congestion and lower traffic speed, hence worsen the urban air quality. On average, 7 million motorcycles are sold to Indonesian citizen annually [7] and this count $80 \%$ of total private motorized vehicles population in Indonesia [8].

There are many previous study conducted to investigate traffic induced air pollution in Indonesia. Some of the studies found many compounds polluted urban air including, criteria pollutants, heavy metals, and some toxic compound such as benzene [9-11]. Others study tried to predict traffic-induced air pollution from available data [12-15]. Most of these study focusing on the ambient air quality, only few study conducted to investigate the pollutant on emission level.

This study aims to investigate the role of motorcycles speed to emission reduction. Motorcycle becomes object of this study since it is the most chosen transportation mode in Indonesia. There are some special condition on 
motorcycle utilization in Indonesia that become the reason for further investigation. Motorcycle emission is worth investigation due to its large population number, the outdated technology, and the variation of fuel used. According to the government regulation, the minimum technology requirement for motorized vehicle including motorcycle is EURO III. However there is no vehicle scrapping policy in Indonesia, so Euro II and older technology are still operated in the road. There is not just single fuel specification sold in Indonesia but various type of gasoline. Fuel used for motorcycle in Indonesia is differentiated by its octane number which are RON 90, RON 92 and RON 95.

\section{METHOD}

Simple method is used for this study. Twenty sample of motorcycle were tested on this study, selected based on 2 latest technology which are Euro III and Euro II and 2 most common fuel type used which are RON 90 and RON 92 Gasoline. Detailed sample number for each category is presented on Table 1 .

Table 1. Motorcycle Samples

\begin{tabular}{|l|l|l|}
\hline & RON 90 & RON 92 \\
\hline Euro II & 5 unit & 5 unit \\
\hline Euro III & 5 unit & 5 unit \\
\hline
\end{tabular}

$\mathrm{CO}_{2}, \mathrm{CO}$, and $\mathrm{HC}$ measured using portable emission analyzer named Autocheck from SPTC USA Corp. Chassis dynamometer, which one of the approved technologies emission measurement was utilized on this study. It is used to obtain emission in idle condition and speeds of $10,20,30,40$ and $50 \mathrm{~km} / \mathrm{h}$. Emission concentration is measured simultaneously from the minimum to the maximum speed, and the sample was taken on steady engine condition. Stability of exhaust temperature and emission concentration gave assumption that engine has reached steady condition. $\mathrm{CO}_{2}$, and $\mathrm{CO}$ were measured on $\%$ unit and ppm unit for $\mathrm{HC}$. To simplify the analysis, all concentration data obtained were converted into $\mathrm{g} / \mathrm{m}^{3}$ unit (see formula (1))

$$
C\left(\frac{g}{m^{3}}\right)=\frac{C_{p p m} \times M}{24.45 \times 10000}
$$

In which:

$$
\begin{array}{ll}
\mathrm{C}\left(\mathrm{g} / \mathrm{m}^{3}\right) & =\text { pollutant concentration in } \mathrm{g} / \mathrm{m}^{3} \\
\mathrm{Cppm} & =\text { pollutant concentration in } \mathrm{ppm} \\
\mathrm{M} & =\text { molecular weight }
\end{array}
$$

Formula (1) is used to convert concentration on ppm to $\mathrm{g} / \mathrm{m}^{3}$. This formula also can be used for converting pollutant concentration on $\%$ unit, which $1 \%$ is equal to 10000 ppm

Velocity pressure and static pressure were measured to calculate exhaust gas velocity for gas volume estimation. This measurement method is derived from EPA method 1a, which is standard method measuring gas velocity from small stack [16]. Gas velocity measurement conducted with utilization of additional stainless steel stack with diameter of $5 \mathrm{~cm}$. Total pressure and velocity pressure are measured with S-type pitot using digital manometer. Formula (2) and (3) is used to calculate the exhaust gas velocity.

$$
\begin{aligned}
& V_{s}=K_{p} \times C_{p} \times\left(\frac{T_{g a s}}{P_{\text {stat }} \times M_{\text {gas }}} \times \Delta P_{p}\right)^{\frac{1}{2}} \\
& K_{p}=\left(2 \times g_{c} \times R_{u}\right)^{\frac{1}{2}}
\end{aligned}
$$

In which:

$\mathrm{V}_{\mathrm{s}} \quad$ = gas velocity in tunnel, $\mathrm{m} / \mathrm{second}$

$\mathrm{C}_{\mathrm{p}} \quad=$ pitot type $\mathrm{S}$ coefficient, dimensionless,

$\mathrm{K}_{\mathrm{p}} \quad=$ constant

$\mathrm{M}_{\text {gas }} \quad$ = gas molecular weight

$\mathrm{P}_{\mathrm{S}} \quad=$ tunnel static pressure, $\mathrm{mm} \mathrm{Hg}$

$\mathrm{T}_{\mathrm{s}} \quad=$ tunnel temperature, Kelvin

$\Delta \mathrm{p} \quad=$ tunnel velocity pressure, $\mathrm{mm} \mathrm{H} 2 \mathrm{O}$

Formula (4) was used to calculate emission on idle condition.

$$
E=C \times V_{s} \times A_{s}
$$

In which:

$$
\begin{array}{ll}
\mathrm{E} & =\text { Emission rate }(\mathrm{g} / \mathrm{second}) \\
\mathrm{C} & =\text { Emission concentration }(\mathrm{g} / \mathrm{m} 3) \\
\mathrm{Vs} & =\text { Gas velocity in tunnel }(\mathrm{m} / \mathrm{second}) \\
\mathrm{As} & =\text { Area of tunnel section }\left(\mathrm{m}^{2}\right)
\end{array}
$$

To calculate exhaust emission on various speed, formula (5) was utilized.

$$
E=C \times V_{s} \times A_{s} \times\left(\frac{1}{V_{k}} \times 3600\right)
$$

In which:

$$
\begin{array}{ll}
\mathrm{E} & =\text { Emission rate }(\mathrm{g} / \mathrm{km}) \\
\mathrm{C} & =\text { Emission concentration }(\mathrm{g} / \mathrm{m} 3) \\
\mathrm{Vs} & =\text { Gas velocity in tunnel }(\mathrm{m} / \mathrm{second}) \\
\mathrm{As} & =\text { area of tunnel section }\left(\mathrm{m}^{2}\right) \\
\mathrm{Vk} & =\text { vehicle speed }(\mathrm{km} / \mathrm{hour})
\end{array}
$$

\section{RESULTS AND DISCUSSION}

On this study, idle emission rate is on gram/second unit and mobile emission rate is on gram $/ \mathrm{km}$ unit. Measurement results from 20 motorcycle samples are presented on Table 2 for idle emission rate, and on Table 3 for mobile emission rate. High standard deviation value and mean-median difference show that there are broad data distribution. To perform more detail data analysis, sample number should be increased on further study.

The result on Table 2 shows that, the longer the vehicle on idling condition, the highest the emission emitted. This study found that dominant pollutant that emitted during idle condition is $\mathrm{CO}_{2}$ compared to $\mathrm{CO}$ and $\mathrm{HC}$. 
Those number can be used to estimate motorcycle emission on intersection and stand still traffic congestion.

Previous studies have also found that idling condition increase the emission level and makes inefficient fuel used $[17,18]$. Idling stop policy is one of idling-emission reducing effort example that was implemented by Taiwan government. Study on motorcycle found that motorcycle user willing be to turn off their vehicle at intersection for $82 \mathrm{~s}$ to $150 \mathrm{~s}$ and this affects to lowering fuel of $1021 \mathrm{~L} /$ hour and $\mathrm{CO}_{2}$ emission of 0.56 metric tons/hour [19, 20].

Typically in Indonesia, idling condition not only happened on intersection, but also when traffic congestion occurs. Besides idling condition, low speed vehicle movement also increase the emission.
This study found that emission tend to be lower on higher speed (Figure 1 and 3). For $\mathrm{CO}_{2}$, and $\mathrm{HC}$ the higher the speed, the lower the emission. However, $\mathrm{CO}$ emission profile is different with other parameters which emission on $20 \mathrm{~km} /$ hour is higher than the $10 \mathrm{~km} /$ hour and on $60 \mathrm{~km} /$ hour is higher than the $50 \mathrm{~km} /$ hour (figure 2 ). This might be caused by variability of the data which mean is about 2 to 3 times of median and standard deviation value mostly higher than mean value (See Table 3).

To get more reliable profile for $\mathrm{CO}$, additional motorcycle should be tested. Generally, emission profiles indicate that the speed between $30-50 \mathrm{~km} / \mathrm{h}$ could be recommended as the most suitable traffic speed in urban area to ensure mobility, safety, and specifically, the lowest emissions.

Table 2. Emission rate on Idling Condition

\begin{tabular}{|c|c|c|c|}
\hline Parameter & Mean & Median & $\begin{array}{c}\text { Standard } \\
\text { Deviation }\end{array}$ \\
\hline $\mathrm{CO}_{2}(\mathrm{~g} / \mathrm{s})$ & 0.157 & 0.092 & 0.150 \\
\hline $\mathrm{CO}(\mathrm{g} / \mathrm{s})$ & 0.025 & 0.006 & 0.078 \\
\hline $\mathrm{HC}(\mathrm{g} / \mathrm{s})$ & 0.002 & 0.001 & 0.004 \\
\hline
\end{tabular}

Table 3. Emission rate on mobile condition

\begin{tabular}{|c|c|c|c|c|}
\hline r Paramete & ${ }_{\mathrm{d}}^{\text {Spee }}$ & $\mathrm{n}^{\text {Mea }}$ & ${ }_{n}$ Media & $\begin{array}{l}\text { Standard } \\
\text { Deviatio } \\
\mathrm{n}\end{array}$ \\
\hline \multirow{6}{*}{$\begin{array}{c}\mathrm{CO}_{2} \\
(\mathrm{~g} / \mathrm{km})\end{array}$} & 10 & $\begin{array}{r}82.3 \\
0 \\
\end{array}$ & 69.11 & 55.01 \\
\hline & 20 & $\begin{array}{r}60.0 \\
7\end{array}$ & 46.40 & 54.49 \\
\hline & 30 & $\begin{array}{r}46.7 \\
9\end{array}$ & 33.27 & 54.47 \\
\hline & 40 & $\begin{array}{r}36.3 \\
8\end{array}$ & 24.33 & 43.53 \\
\hline & 50 & $\begin{array}{r}30.2 \\
1 \\
\end{array}$ & 23.13 & 23.43 \\
\hline & 60 & $\begin{array}{r}27.0 \\
3\end{array}$ & 21.54 & 18.37 \\
\hline \multirow{6}{*}{$\underset{(\mathrm{g} / \mathrm{km})}{\mathrm{CO}}$} & 10 & $\begin{array}{r}11.4 \\
7\end{array}$ & 4.54 & 21.72 \\
\hline & 20 & $\begin{array}{r}12.8 \\
5 \\
\end{array}$ & 2.69 & 26.73 \\
\hline & 30 & 7.28 & 2.34 & 11.58 \\
\hline & 40 & 4.54 & 2.63 & 5.06 \\
\hline & 50 & 4.18 & 2.27 & 4.96 \\
\hline & 60 & 4.90 & 2.33 & 7.36 \\
\hline \multirow{6}{*}{$\begin{array}{c}\mathrm{HC} \\
(\mathrm{g} / \mathrm{km})\end{array}$} & 10 & 0.55 & 0.32 & 0.59 \\
\hline & 20 & 0.28 & 0.22 & 0.24 \\
\hline & 30 & 0.21 & 0.15 & 0.22 \\
\hline & 40 & 0.14 & 0.11 & 0.13 \\
\hline & 50 & 0.13 & 0.13 & 0.08 \\
\hline & 60 & 0.10 & 0.09 & 0.05 \\
\hline
\end{tabular}


The Third International Conference on Civil Engineering Research (ICCER)

August $1^{\text {st }}-2^{\text {nd }}$ 2017, Surabaya - Indonesia

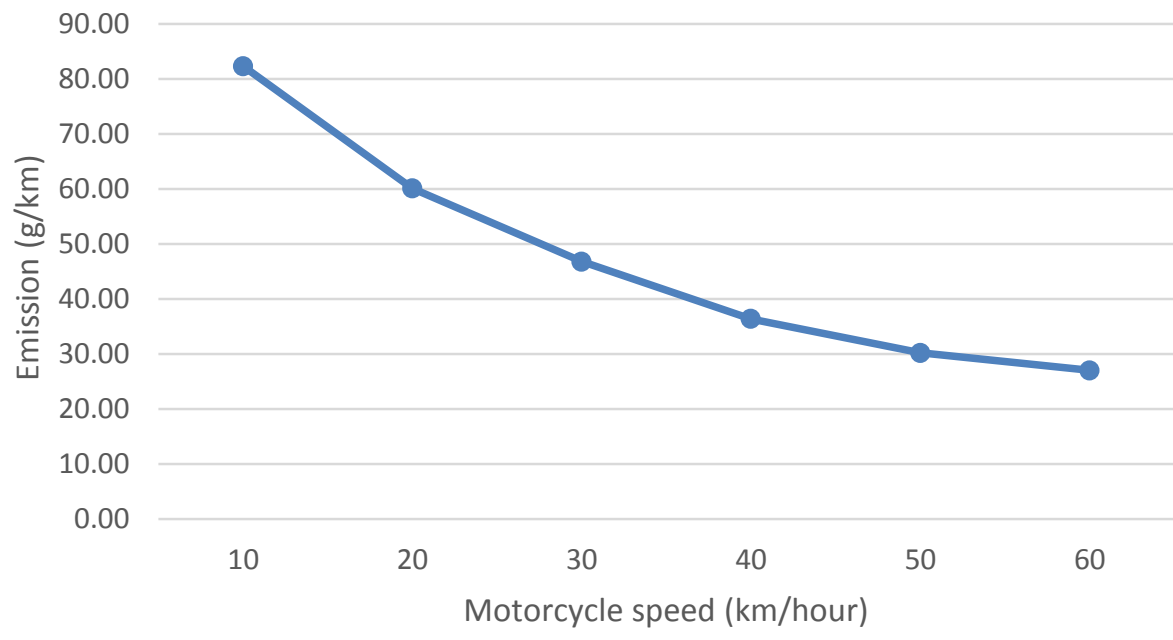

Figure 1. Speed-related $\mathrm{CO}_{2}$ emission profile

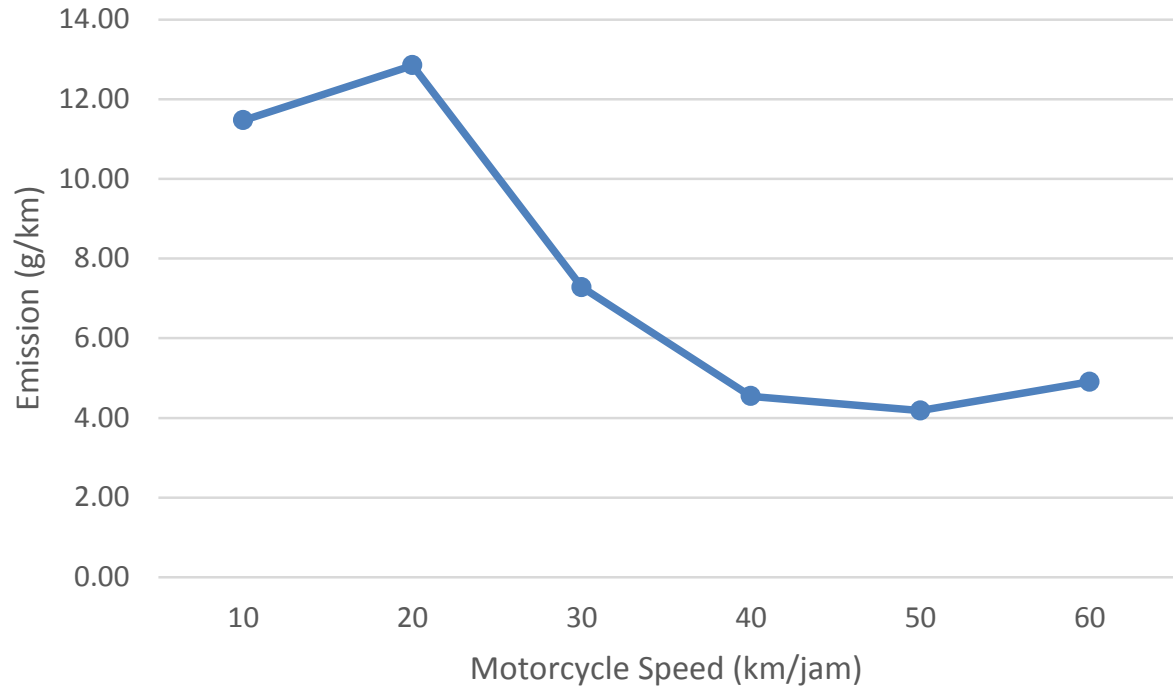

Figure 2. Speed-related CO emission profile

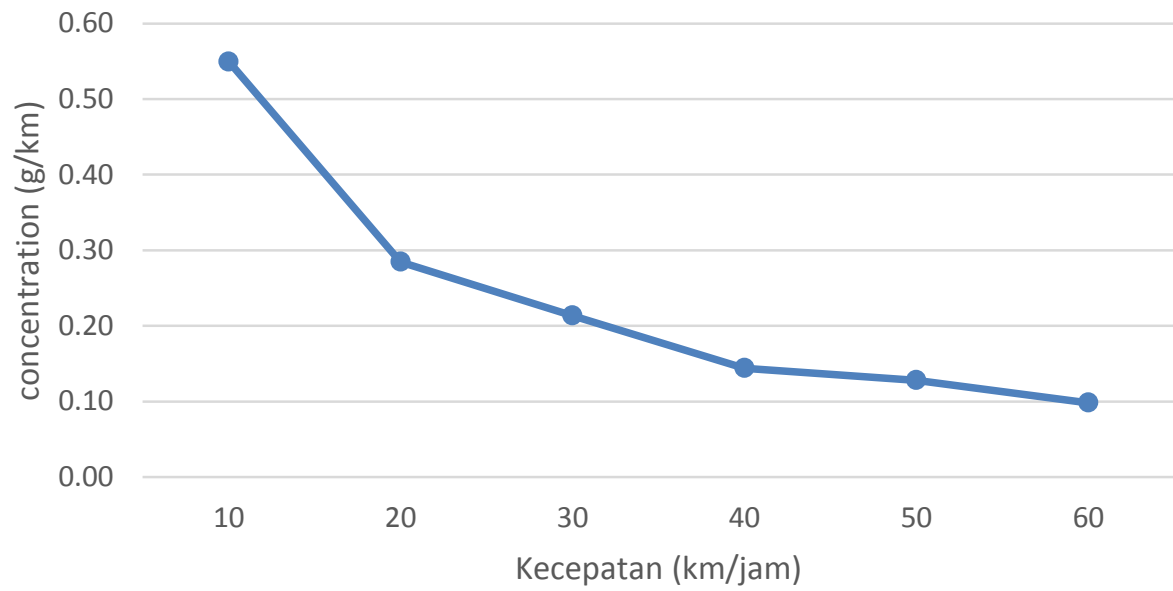

Figure 3. Speed-related HC emission profile

Even with relatively small number of data, non-linear relationships similar to the multinomial to emission pattern used for developing European emission factors 
[21] were found. However, for European pattern the emission is slightly increase when the speed is higher than $50 \mathrm{~km} /$ hour. One factor that could affect this pattern difference is fuel usage. Ideally, gasoline category II on World Wide Charter [22] should be used for Euro II and Euro III but the quality of fuel commonly sold in Indonesia still not meet category II standard. However, very limited data available in Indonesia to get the picture of transportation sector impact, especially to urban air quality. So, this finding might become a valuable input for transportation management as a part of environmentally sustainable transportation.

\section{CONCLUSION}

This study suggested measurement method to get real world emission from motor cycle using simple instrumentation. On this study it is found that the highest the motorcycle speed, the lowest the $\mathrm{CO}_{2}, \mathrm{CO}$ and $\mathrm{HC}$ emission. According to this result, traffic congestion which motorcycle mostly on idle and lower speed condition might worsen urban air quality. To meet environmentally sustainable transportation, this study suggests to reduce unnecessary idling condition and recommend average speed on urban area of $30-50$ $\mathrm{km} /$ hour. Besides the driving safety reason, that speed also could reduce fuel cost and emission. More motorcycle samples are needed to get better data resolution and accuracy.

\section{ACKNOWLEDGEMENT}

This study is part of a research funded by the Ministry of Research and Higher Education through Penelitian Unggulan Perguruan Tinggi 2016 "Dampak Emisi Transportasi Terhadap Konsentrasi Ambien Pencemar Udara Bersifat Toksik dan Karsinogen di Perkotaan". The authors also thanked Mr. Mochamad Pradipto Leksono for his assistance and discussion during emission tests were undertaken.

\section{REFERENCES}

[1] Arnott, R. and K. Small, The economics of traffic congestion. American Scientist, 1994. 82

[2] Barth, M. and K. Boriboonsomsin, Real-World Carbon Dioxide Impacts of Traffic Congestion. Transportation Research Record: Journal of the Transportation Research Board, 2008. 2058: p. 163-171.

[3] Grote, M., et al., Including congestion effects in urban road traffic $\mathrm{CO} 2$ emissions modelling: Do Local Government Authorities have the right options? Transportation Research Part D: Transport and Environment, 2016. 43: p. 95-106.

[4] Pasquale, C., et al., Two-class freeway traffic regulation to reduce congestion and emissions via nonlinear optimal control. Transportation Research Part C: Emerging Technologies, 2015. 55: p. 85-99.

[5] UN. Sustainable Development Goals, 17 Goals to Transform Our World. Goal 11: Make cities inclusive, safe, resilient and sustainable 2017 [cited 2017; Available from: http://www.un.org/sustainabledevelopment/cities/.

[6] Final Report: Strategi Nasional Environmentally Sustainable Transportation Indonesia. 2014, Institut Teknologi Bandung.
[7] AISI, Motorcycle Production Wholesales Domestic and Exports, in 1996 - 2014. 2017.

[8] BPS, Perkembangan Jumlah Kendaraan Bermotor Menurut Jenis tahun 1987-2013, in 2016. 2016: Jakarta.

[9] Santoso, M., et al., Sources identification of the atmospheric aerosol at urban and suburban sites in Indonesia by positive matrix factorization. Sci Total Environ, 2008. 397(1-3): p. 22937.

[10] Santoso, M., et al., Preliminary study of the sources of ambient air pollution in Serpong, Indonesia. Atmospheric Pollution Research, 2011. 2(2): p. 190-196.

[11] Yudison, A.P., et al., Transport Induced Benzene Pollution in Urban Area - Pencemaran Benzena dari Sektor Transportasi di Perkotaan (in Bahasa Indonesia). Seminar Nasional Ilmu Pengetahuan, Teknologi, dan Seni (Semnas-IPTEKS), Institut Teknologi Bandung, 19-20 April 20172017.

[12] Amri, S. and Driejana, A Simple Approach to Estimate GriddedValue in High-Resolution GHG Emission Map of Road Transport Sector. Proceedings of Eastern Asia Society for Transportation Studies, 2011. 8

[13] Driejana, et al., Spatial Mapping of CO2 Emissions from Major Roads in Bandung City, Indonesia. Proceedings of Eastern Asia Society for Transportation Studies, 2011. 8.

[14] Yudison, A.P. and Driejana, Modeling of Traffic-Induced NO2 Concentration to Predict the Indoor Air Quality in Houses Near Major Road. Proceedings of Eastern Asia Society for Transportation Studies, 2011. 8 .

[15] Yudison, A.P. and R. Driejana, Development of Indoor Ai Pollution Concentration Prediction by Geospatial Analysis Journal of Engineering and Technological Sciences, 2015. 47(3): p. 306-319.

[16] USEPA, Method 1A-Sample and Velocity Traverses for Stationary Sources With Small Stacks or Ducts. USA.

[17] Rahman, S.M.A., et al., Effect of idling on fuel consumption and emissions of a diesel engine fueled by Jatropha biodiesel blends Journal of Cleaner Production, 2014. 69: p. 208-215.

[18] Shancita, I., et al., A review on idling reduction strategies to improve fuel economy and reduce exhaust emissions of transport vehicles. Energy Conversion and Management, 2014. 88: p. 794 807.

[19] Jou, R.-C., et al., The willingness-to-accept in time compensation for turning off the idling engine of motorcycles at red lights in Taiwan: A short note. Transportation Research Part D: Transport and Environment, 2011. 16(3): p. 251-256.

[20] Jou, R.-C., Y.-C. Wu, and K.-H. Chen, Analysis of the environmental benefits of a motorcycle idling stop policy at urban intersections. Transportation, 2011. 38(6): p. 1017-1033.

[21] Boulter, P.G., T.J. Barlow, and S. McCrae, Emission Factor 2009, in Report 3 - Exhaust Emission Factor For Road Vehicle in The United Kingdom. 2009, TRL Limited.

[22] World Wide Fuel Charter. 2013 